\title{
SURVEY EXPERIMENTS
}

\author{
Landon Schnabel*
}

\begin{abstract}
Note: This is the chapter on survey experiments for a forthcoming handbook for research methods in the study of religion.
\end{abstract}

Final Draft Date: 2019-05-23

\begin{abstract}
:
Survey experiments are burgeoning in the study of religion/s. A survey experiment is simply an experiment conducted on a survey. Survey experiments address key limitations of nonexperimental surveys and experiments on convenience samples. Surveys are great for speaking to patterns in a broader population, but are limited in their ability to examine causal mechanisms (i.e., what exactly causes what). Lab experiments speak to causality, but using convenience samples limits generalizability (i.e., the extent to which the patterns can be expected to apply to a wider population). Survey experiments combine strengths from survey methods and experimental methods, providing leverage on both generalizability and causality. By using population-based sampling frames from survey research, survey experiments can generalize to a broader population. And by using experimental methods, specifically randomly assigning people to experimental conditions, survey experiments can establish whether one thing causes another. Although survey experiments are becoming more common in the social scientific study of religion, we are only beginning to scratch the surface of the range of questions and contexts that could be explored with survey experiments.
\end{abstract}

\section{Chapter summary}

- A survey experiment is an experiment conducted on a survey.

- A survey experiment is a powerful tool for gaining leverage on both generalizability and causality.

- Survey experiments are generalizable when they are population-based-or, in other words, when those participating in the survey experiment are a random sample of the population of interest. When a survey experiment is population-based, the implications for the broader population of interest can be drawn with a certain level of confidence.

\footnotetext{
* Direct correspondence to Landon Schnabel, Department of Sociology, Indiana University, 744 Ballantine Hall, 1020 E. Kirkwood Ave., Bloomington, IN 47405. Email: lpschnab@indiana.edu.
} 
- Survey experiments speak to causality because they randomly assign people to experimental conditions, thereby establishing the effects of researcher-formulated causes. Whereas surveys are often limited by only speaking to correlation (the existence of a relationship but not causal ordering), survey experiments provide greater insight on causal mechanisms.

- Survey experiments can be conducted across the range of survey delivery methods (e.g., phone, in person, etc.), but online survey experiments provide additional options for experimental treatments (e.g., longer text vignettes, audio-visual treatments, etc.).

- Survey experiments are not without limitations and constraints. Population-based survey experiments can be expensive. And whereas researchers have more control over the quality of the environment in a lab, survey experiments are limited by the same constraints of other surveys: the researchers typically have limited control over the circumstances under which the survey is completed.

- Although survey experiments are becoming more common in the social scientific study of religion, we are only beginning to scratch the surface of the range of questions and contexts that could be explored with survey experiments.

\section{Introductory overview}

Survey experiments are among the most exciting, and as yet underutilized, methods in the study of religion/s. By combining strengths from both survey methods that allow for generalizing to larger populations and experiments that can establish causality (see Chapters $* *$ and $* * *$ for more general looks at surveys and experiments), survey experiments provide unique leverage for empirical questions related to religion/s.

Surveys, and population-based surveys in particular, are great for when you want to find out information about a large population and be able to generalize about broad processes. You could survey a thousand people and get a sense of broad patterns for an entire country. But one of the primary weaknesses of surveys is that they typically aren't great at determining causal ordering, or exactly what caused what. For example, if you field a survey and find a relationship between religious service attendance and physical and mental health it can be hard to determine whether religious service attendance makes you healthier, or if being healthier simply makes it easier to attend services more regularly. Beyond the issue of which way the relationship goes, 
it's even possible that you found a correlation simply because some other thing influences both the factors you're looking at. For example, maybe some sort of personality characteristic such as conscientiousness leads to both more regular religious service attendance and better health, making it look like they're related to one another. It could simply be that highly conscientious people are more likely to follow through with whatever they think they should do, which could include getting more regular medical care, exercising, eating well, etc. and, for a religious person in a congregation-based religion, attending religious services regularly. If that were the case, attendance and health could be correlated with one another without any no cause-and-effect relationship between them (i.e., increasing or decreasing one doesn't impact the other).

Where surveys can fall short in determining exactly what causes what, experiments are great for addressing causal ordering. For example, if you randomly assign respondents to a treatment group or a control group and then compare their outcomes, you can state with a level of confidence that any differences were caused by the treatment. Imagine you are wondering whether mindfulness decreases stress. You could bring a group of people into a lab and have them participate in an activity that induces stress, such as a math test, and see if mindfulness can alleviate some of that stress. You randomly assign people to a treatment or control condition, with the treatment group going through a guided breathing exercise before the test and the control group taking the test without the breathing exercise. You then measure stress biomarkers and test scores across groups. If people randomly assigned to participate in a guided breathing exercise had, on average, significantly less stress and better test scores than the comparison group you would know that the breathing exercise had a causal effect.

One of the most important benefits to an experiment like this is that you would know the treatment caused the differing outcomes across groups. By randomly assigning people to 
treatment groups, you know that the groups are otherwise similar and that the treatment is what causes different outcomes across groups. This fixes the problem of selection (i.e., that some people are more likely to select into something) in observational research, which observes things after the fact rather than making an intervention to randomly assign treatment vs. control conditions as in experimental research. For example, we might imagine that a researcher thinks that going through religious rites of passage (e.g., a bat or bar mitzvah) as a child makes people more committed to their religion as adults. A survey asking people whether they went through a religious rite of passage as a child and how strongly they identify with their religion now would be severely limited: the types of people who would be more likely to be religiously committed as adults would be more likely to have gone through those rites of passage. We might expect, for example, that the people who chose to go through those rites of passage were more religiously committed as children than those who didn't go through them, that their family and friends were more religiously committed, and so forth. Therefore, it might simply be these other things that made people more likely to select into going through the rite of passage, rather than the act of going through the rite of passage itself, that leads to differences between those who went through the rite of passage and those who didn't.

For a variety of reasons researchers don't randomly assign people to some types of treatments - like whether a child goes through a religious rite of passage — but when experiments are ethical and feasible they are arguably the best way to test whether one thing is actually the cause of another. For example, a non-experimental survey might ask people whether they engage in mindfulness practices and how much stress they experience. But even if there is a strong correlation it may simply be that people who are more committed to living less stressful lives, people who have more education or income, and/or people with more flexible time in their 
schedules are more likely to engage in mindfulness practices. Therefore, a lab experiment such as the one laid out above in which some people are randomly assigned to engage in a guided breathing exercise is a great way to test whether mindfulness practices causally reduce stress.

One of the biggest limitations with many lab experiments, however, is that the potential for generalizability is often limited. You know how the treatments affected the people who came in for the study, but the people who came in typically aren't representative of the population as a whole. In fact, many experiments are conducted using college students at a single university. So you know how the treatment affects students at that university, but you don't know what the effect might be among the general population.

What if you want to both know what causes what and want to be able to generalize to how something affects a larger population? Survey experiments can combine strengths from the survey approaches and experimental approaches noted above (and discussed in more detail in Chapters ** and **). Whereas many surveys cannot establish generalizability and lab experiments can be limited in their generalizability, population-based survey experiments can establish both causality and generalizability. But what exactly is a survey experiment, and what is a population-based survey experiment?

\section{What's a survey experiment?}

Put simply, a survey experiment is an experiment conducted on a survey. There are many ways to conduct an experiment on a survey, including any number of scenarios where you randomly assign some people to see one thing on the survey and other people to see something else. There are a number of different types of surveys, and ways they can be conducted. For example, a student could hand out paper-and-pencil surveys to the people in their class, a religious leader could send out emails to their congregants with a link to fill out an online survey, a survey 
research center could call random phone numbers and ask them questions from a survey instrument, or a community organization could send out a team of interviewers to ask people questions in person outside an event. Surveys are used all the time, and not just by people who would identify as survey researchers. Stores survey their customers about their experiences, pollsters ask people about their views on political candidates and current events, and if you're reading this chapter for class there's a good chance your school will survey you about the course at the end of the term.

Experimental elements can be incorporated into surveys in many ways. If you've randomly assigned people to view different versions of a survey, you've conducted a survey experiment. In other words, the basic technique for a survey experiment is to vary a feature of the survey and measure whether exposure to that treatment affects how people respond to the questions that follow it. For example, text (or some other stimulus, such as images, audio, or video) can be used to 'prime' people. A prime is something frequently used in laboratory experiments where people are exposed to a stimulus earlier that may influence how they respond to later questions - often without being consciously aware that their response was shaped by what they were exposed to earlier. A prime could involve presenting some subjects with just a single word, something more complex like having them read or watch something, or, in a lab setting you could even have people participate in a priming activity. A survey experiment on religion could utilize priming by, for example, presenting a scriptural text about care for the poor before asking people whether they support welfare. The text would be shown to some people (the treatment group) and not shown to others (the control group). Such a study might find a 'priming' impact on those who believe in that specific scripture-i.e., having read the text may 
prime them to try to be consistent with the text in order to avoid cognitive dissonance with their belief in the text—but no impact on those who don't believe in it.

Another approach, perhaps the most common type of survey experiment, is to have people read different versions of a vignette and then answer some questions about it. Vignettes are short stories in which elements of a situation are varied. After having people read the vignettes, you then ask them to evaluate someone or something from the story. To use a realworld example, in a vignette-based study my collaborators and I presented a situation where people tried to purchase services from a business and were refused services for either religious or for non-religious reasons. After people read about the scenario, we then asked them whether or not the business should be able to refuse services or whether they should have to provide the same services they provide to other customers. I'll discuss this study in some more detail later, but the key finding is that people were just as likely to support refusal for non-religious reasons as for religious reasons.

Researchers could apply a similar approach to determine not just how people would evaluate people and situations, but also to get at the types of choices they'd make. If you ask someone explicitly whether they'd be willing to vote for a political candidate who is a woman or a religious minority, they might say they'd be willing to vote for that candidate because they see it as the more socially desirable response. If you want to get at more implicit than explicit processes, you could instead present a pair of potential candidates and ask which one they'd be more likely to vote for. If you present different versions of the pairings to different people, systematically varying the things you want to test while keeping everything else about the candidates the same, you could compare the impact of those varied characteristics on how likely people would be to vote for someone. 
For instance, if a researcher wanted to understand whether people are more likely to vote for religious or secular candidates and whether that varies by whether the candidate is a man or a woman, they could create profiles of equivalent candidates who are either religious or secular and either a man or a woman. Such a study might find that people are more likely to say they'd vote for a woman or a secular person when asked directly (e.g., 'Would you be willing to vote for a woman candidate, yes or no?') than when faced with a candidate who actually has those characteristics. It's also possible that the impact of a candidate's secularity would vary by their gender, with people perhaps more harshly penalizing a woman than a man for being secular in terms of how likely they would be to vote for them.

\section{Online survey experiments}

Vignette experiments can be incorporated into phone and mail surveys, but online delivery can be especially effective for survey experiments. For example, respondents can more quickly read a vignette than listen to one read out by a phone interviewer. Beyond the gain in efficiency for vignette experiments - which is one of the most, if not the most, common type of survey experiment — online surveys can easily incorporate various forms of media. An online survey experiment could incorporate multimedia elements such as images, audio clips, and video clips.

For the sake of illustration, imagine you've previously done a vignette study on the impact of a person's gender and their religion on how they're perceived, and now you want to understand the impact of religious garb. Rather than just describe the person's garb, you could include a picture along with the vignette. Let's say you've previously found some interesting patterns about how people would feel about having someone as their neighbor, child-care provider or political representative based on the imagined person's gender and religion. Now, in addition to varying the gender and religious affiliation of the person in the scenario, you could 
also show an accompanying picture that is meant to represent the person. The pictures could then show the same person but vary their garb so that, for example, one group of respondents to your survey sees a picture of a woman with a hijab and the other group sees a picture of the same woman without a hijab. You could then determine the impact of this religious garb on people's perceptions.

You don't have to just use pictures of people, however, and could instead vary other types of images or visual elements in an online survey. For example, you could present resumés varying certain characteristics and then ask your respondents how likely they would be to hire the person and/or what salary they think the person should get. Or you could show any number of things that could be presented visually, such as screenshots of social media profiles, pictures of artwork, or images of religious symbols.

In addition to static images, a survey experiment delivered online could include audio or video clips. A wide array of relevant audio or video clips could be used, including songs, speeches, advertisements, news clips, etc. For example, maybe a researcher wants to determine whether the same message delivered in a different way would be evaluated differently, or yield different sets of emotional responses. They could, for example, record two versions of the same message, one time delivered in a loud and condemnatory tone and then another time delivered in a soft and compassionate tone to determine whether and how people respond to the message varies by the tone it's delivered in.

Because of the unique opportunities afforded by online survey experiments, as well as the rise of online delivery options, survey experiments are increasingly conducted online. Online survey experiments often use Amazon Mechanical Turk (mTurk) workers or existing online panels of respondents maintained by survey, polling, and market research organizations such as 
Qualtrics, YouGov, Knowledge Networks, GfK, etc. Survey experiments can also be conducted by sending targeted invitations (e.g., to members of an organizations) or by recruiting participants via online advertisements.

mTurk is a crowdsourcing platform where businesses and individuals can post tasks for workers to complete. Survey researchers can post surveys as tasks, paying respondents to complete them. This is a relatively cost-effective way to get respondents for your survey experiment because you choose how much workers are paid to complete tasks. Many people who post tasks undercompensate mTurk workers, and you'll want to think about the ethical implications of how much you pay your respondents.

There are several limitations to using mTurk samples because mTurk yields a particular set of respondents who are not representative of the broader population. An issue particularly salient to studies on religion is that American mTurk samples tend to be quite secular (Lewis et al. 2015). Moreover, like other sources for online samples, respondents are only available in some locations. Most mTurk workers are based in the United States or India, and you could get a fairly large sample of mTurk respondents from those countries. There are mTurk workers based in many other countries, but outside of the United States and India the numbers are fairly small: according to a 2018 paper on the demographics of mTurk workers, about nine-in-ten mTurkers are located in either the United States or India (Difallah, Filatova, and Ipeirotis 2018). Therefore, if you wanted to conduct a survey experiment in other countries you'd need to make sure there are enough potential respondents (i.e., mTurk workers) for your purposes before planning to use mTurk for your survey experiment.

Despite the limitations of which countries could be surveyed — and the issues with representativeness of those countries — one could make the case that mTurk respondents provide 
a broader subset of the wider population than undergraduates at one or a few colleges or universities in a country, which is the sampling frame used in many lab experiments. This is especially true if you do a short pre-survey screen to find a set of respondents who are demographically similar to your target population.

Other options for getting respondents provide samples that better approximate a crosssection of the public, but generally cost more. Although several survey firms that maintain panels of readily-available respondents from which you can purchase a sample focus on the United States, survey panels can be found in a wide range of countries. GfK and YouGov, for example, both market themselves as global research firms, providing the ability to conduct survey experiments in many countries around the world. One benefit of using existing panels of respondents is that you can often field your survey on targeted subgroups of respondents. For example, when I fielded a survey experiment on a Qualtrics panel I was able to oversample Jews and Muslims in the United States. Using existing panels will also typically allow you set to benchmarks for a set of respondents that approximate the characteristics of the general public on factors like gender, race, education, and age (as noted above, you can do this with mTurk as well, but you'll need to do the prescreen yourself). Some panels, such as the AmeriSpeak panel managed by the National Opinion Research Center at the University of Chicago, are populationbased.

\section{Population-based survey experiments}

All types of surveys can include experimental elements, but population-based survey experiments are a special type of survey experiment where you can take advantage of one of the greatest strengths of surveys with population-based sampling frames (i.e., more external validity than lab experiments, and even generalizability to a broader population). Population-based 
survey experiments are a subset of survey experiments in which the sample (or the people filling out the survey) are representative of a larger group. A sample is representative when it is randomly selected from the population of interest, with each potential respondent in the population having the same chance of being selected.

By providing leverage on both generalizability and causation, population-based survey experiments avoid key limitations of many surveys and experiments. Issues of population-based sampling for surveys have already been covered in Chapter **, so I will here only note that one of the easiest, though not necessarily cheapest, methods for obtaining a population-based sample is to work with a survey organization that maintains a population-based sample. For example, the National Opinion Research Center at the University of Chicago maintains a population-based panel (it's called the AmeriSpeak panel). You can pay them to field a survey experiment using their respondents.

\section{Limitations and practical issues}

I've already talked about some of the key strengths of survey experiments, but there are some important limitations as well. Other chapters in this volume have covered general limitations when using surveys or when using experiments. Here I'll focus primarily on limitations that arise when survey and experimental methods are combined. Rather than just lay out the problems, I'll also provide some recommendations for how to minimize those limitations.

One of the key limitations for survey experiments is a function of how surveys are typically delivered. In a lab environment, researchers have more control over ensuring the data from their experiments are of high quality. For example, they can ensure that their lab assistants are trained, confirm who's participating in the study, and make sure people are paying attention. Careful sampling and survey delivery can help alleviate some of these problems (which can be as 
serious as the same person filling out the same survey multiple times or even a bot filling out the survey), but it's hard to know the extent to which people were paying attention when taking the survey. And the extent to which respondents are paying attention could bias the estimates of the effects of the treatments in a survey experiment (e.g., differences across conditions could be underestimated if people aren't paying attention when reading vignettes).

People who conduct survey experiments can — and I think should—incorporate data quality checks in their surveys. For example, you could include instructions before a question telling people to select some specific response regardless of how they would otherwise answer it, which helps to make sure people are paying attention and reading directions carefully. And if you're using vignettes or other treatments where you want to make sure the person paid attention to the treatment, you can ask a fact-based question about what they read or saw, such as some key characteristic about the person or scenario depicted (e.g., what was the religion of the person described, where did the scenario take place, etc.). If conducting a survey experiment online, you can - depending on the platform used to administer the survey - look at metadata that could reveal strange patterns (e.g., lots of surveys filled out from one specific location, surveys that were filled out much more quickly than any other surveys, etc.). You can also look at the data case-by-case to see if the responses given by a particular respondent make at least some sense, or if they point to anomalies (e.g., there's a phenomenon in survey research where some small percentage of respondents may be jokesters, filling out the survey with what they think are interesting or unique responses, such as saying they're 8 feet tall, have sex 1,000 times a week, and are 110 years old).

Survey experiments, like other surveys, are good at measuring what people are willing to say they think or do. But they aren't as good at measuring what people actually do. For example, 
a survey experiment might find that it seems like people seem would be just as likely to hire a Muslim employee as a Christian employee. But if you were to conduct an audit study or field experiment in the real world, you might find different patterns. There are things you can do to try to encourage people to fill out a survey truthfully_highlighting confidentiality, explaining why you're asking what you're asking, carefully choosing how you word and where you place sensitive questions, etc. - but you still can't know with certainty that what people say they would do on a survey is what they would actually do.

Survey experiments can be quite costly, and depending on the situation you may only have one chance to get things right. Lab experiments are costly as well, but if you have a lab up and running you can conduct follow-up experiments to address issues or focus in on why a treatment mattered. Experiments, including survey experiments, are great for showing whether a treatment causes an outcome, but exactly why it mattered may be less clear. Therefore, researchers should go into experiments with clear theoretical expectations for why they expect the treatment to matter. Without clear expectations as to what exactly you're testing, even if you find the treatment matters you may not know why. And without clear theoretical expectations

In addition to having clear theoretical expectations for why your treatment should matter, you need to be meticulous with how you design your experiment so that if you find no effect you know it is a meaningful non-effect rather than the result of a poorly designed experiment. Imagine that you develop a theoretically-informed expectation that reading religious texts gives people comfort in hardship. You design an experiment where half of people read an excerpt from a religious text and half of people don't. Then you ask people how they feel about the hardships they are facing. You then find that your treatment doesn't seem to matter. Realizing you hadn't thought enough about the expectations for why reading a religious text would matter, you now 
recognize you should have selected the text more carefully (it should be from a scripture matched to the respondents' religious tradition, it should be an excerpt that is comforting, etc.). You also wonder whether you should have asked whether respondents see the scripture as inspired (maybe it only matters for people who see it as inspired) and whether they regularly read the scripture (maybe it matters more for those who had developed the ritual experience, or maybe it matters more less frequent readers for whom it was a more distinctive experience). If you regularly have participants coming into the lab you can just run some more studies testing additional potential mechanisms for why reading a text does or doesn't matter. But if this was a survey experiment for which you could only field one study, you'd be in the tough spot of having null findings and no idea whether they were truly null findings or just the result of a poorly designed experiment. One solution is to pretest your survey experiment in less costly settings before fielding it. For my survey experiments, I typically run pretests with undergraduates before fielding the survey on a national sample.

Related to the point above, survey experiments - like other experiments - can clearly establish causal ordering and show that the treatment caused the outcome, but the specifics of why exactly the treatment mattered may be less clear. Therefore, not only do you need clear and precise theoretical expectations (and maybe some pretest results) to avoid running a poorly designed experiment, you also need those expectations in place to know what exactly it is you're testing and what your results mean. Let's think about medical research for a moment to help illustrate the point. In randomized drug trials (i.e., experiments), medical researchers go into the study with an expectation that a drug will yield some specific beneficial outcome for those who take it. They hopefully have a clear reason why they expect it to matter because the experiment will be costly and while it will be able to show the effect of taking the drug, it may not be able to 
show exactly why that effect occurs (or whether that same effect could be expected for all types of patients). In other words, experiments tend to be better at testing whether something you think matters actually matters (confirmation) than just trying things out to see what happens (exploration). Even if you find an effect and know that the treatment you exposed people to does something, you may not know why exactly it does it. In addition to developing clear and precise expectations before conducting survey experiments, I frequently include open-ended follow questions that ask random subsets of the respondents to explain why their answers. Their responses give me insight into how people are interpreting the treatments and outcomes, and help provide an accounting for both expected and surprising findings.

In addition to the limitations of survey experiments, there are also practical issues with collecting high-quality experimental survey data. In addition to making sure you are careful with how you design the experiment, construct the instrument, and determine the sampling frame, you also need to be able to field it. If you're just interested in how your friends, coworkers, clients, or other people who you have ready access to would respond to your survey, you can probably field the survey experiment yourself (after getting the proper approval for the study of course). But if you want to conduct a nationally-representative survey experiment that will allow you to generalize to the population of people in your country of interest, you're going to need substantial funds. There are an increasing number of platforms that provide access to different ranges of respondents, and typically the more representative the sample they provide the more it will cost.

There's a special opportunity available for those planning to conduct web-based survey experiments focused on the United States. The Time-sharing Experiments for the Social Sciences (TESS) program, which is funded by the U.S. National Science Foundation, provides a 
competitive opportunity for researchers to field nationally-representative survey experiments.

For this opportunity, researchers submit proposals, which are then peer-reviewed. Those that are accepted are then fielded. Currently, these surveys are fielded on the AmeriSpeak panel maintained by the National Opinion Research Center at the University of Chicago. For more information about TESS, you can visit their website at http://www.tessexperiments.org/. You can also fund survey experiments in the typical ways researchers fund data collection, such as applying for grants. Some organizations focused on the study of religion provide opportunities to apply for grants that can be used to fund survey experiments including the American Academy of Religion, Association for the Sociology of Religion, Religious Research Association, and the Society for the Scientific Study of Religion.

Once you determine where you will field your survey experiment, you'll also need to translate your instrument to a format that will work with your delivery method. If you're fielding the survey experiment with a physical questionnaire, you will need to create multiple versions of the questionnaire to match all permutations of your experimental manipulations. If you're embedding experimental elements in a phone survey using Computer Assisted Telephone Interviewing (CATI) techniques, you'll need to ensure the programming includes the appropriate randomization. If you're fielding the survey online, you'll need to make sure the programming is done to prepare your survey instrument. Depending on the platform where you're fielding your online survey experiment, you may be programming it yourself or others may be programming it for you. If you're actively recruiting participants yourself, you'll probably be responsible for programming the survey (or finding someone to program it for you). You can use existing software (such as Qualtrics) to assist you in programming the survey experiment. If you're using a panel maintained by a survey research organization, the organization may program the 
experiment for you or they may just provide you with respondents who will fill out the survey instrument you've programmed. At the end of this chapter I'll provide some additional readings that will help you with the nuts and bolts of carrying out a survey experiment.

Although there's often substantial work involved in preparing experimental elements for surveys, once you've collected the data it is typically fairly straightforward to analyze. With nonexperimental survey data you have to worry about issues with controls, the direction of relationships (i.e., whether A causes B or B causes A), and whether there are omitted variables that would explain away the relationship. Therefore, the analysis of such non-experimental survey data can get very complicated and still not yield clear results that you can be confident in. But when you collect experimental data you know the treatment causes the outcome rather than the other way around (it's impossible for responses given after the treatment to cause the treatment) and that the relationship isn't due to some outside factor making it seem like two things are causally related when in fact they're not. Although the analysis of data from survey experiments is often more straightforward than non-experimental data, you'll still need to make sure to check data quality, determine whether the treatment has a different effect on different groups in your sample, and all the other things you need to do when analyzing experimental data with human subjects.

\section{Examples}

Now that I've talked about what survey experiments are and discussed some of their strengths and weaknesses, I'd like to share some actual examples of survey experiments on religion. I'll start with one I did, laying out the components and then showing you the findings. Then I'll discuss some other survey experiments on religion. 
Legislatures and courts in the United States were debating whether businesses could deny services to same-sex couples for religious reasons. Brian Powell, Lauren Apgar, and I decided to conduct a survey experiment on the conditions under which Americans would support refusal of services. Despite all the legal debate about service-refusal, and the conditions under which it should or should not be legal, little information existed on the conditions under which Americans would support refusal. We were particularly interested in the impact of three factors: 1) whether the refusal was for religious reasons or not, 2) whether the refusal was on the basis of sexual orientation (same-sex couples) or race (interracial couples), and 3) whether the business refusing services was a self-employed individual or a corporation.

We designed a vignette-based survey experiment in which a couple attempts to purchase wedding invitation portraits and is refused service. We submitted a proposal for the study to TESS, and were thus able to field the study with a population-based sample representative of the American public. We asked study participants whether it was okay for the business to refuse services or whether the business should provide the same services they provide to other customers. Our vignettes were a 2x2×2 full factorial design (illustrated by the diagram in Figure 1) that systematically varied the reason for refusal, whether it was a same-sex couple or interracial couple refused service, and whether it was a self-employed individual or a corporation that refused service. 
Figure 1: 2x2x2 Factorial Design for Business Service Refusal Survey Experiment

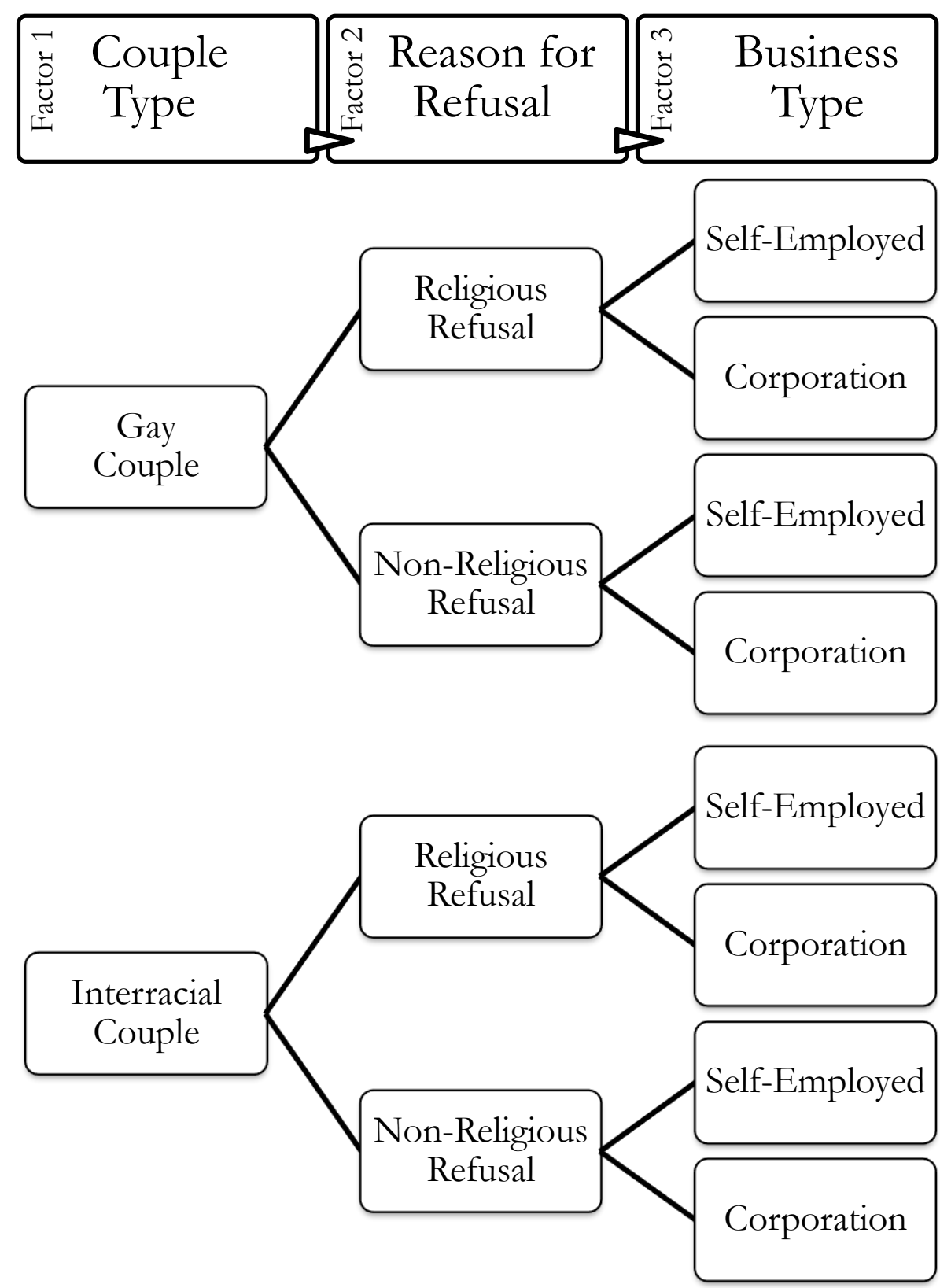

With the experimental manipulations (or what we systematically varied) in brackets, here's what the vignettes looked like:

[Michael and Jason, a gay couple/Michael and Jennifer, a black man and a white woman] are getting married and want to have photos taken to send out with their wedding invitations. They went to a [self-employed photographer/photography studio in a large chain store] because they heard [he was the best photographer/it was the best place] in the area for 
engagement portraits. The photographer refused to take their picture. He explained that [(because he is religious/although he is not religious)/ (because the corporate chain owner is religious/although the corporate chain owner isn't religious)] [he/the owner] doesn't approve of [gay/interracial] marriage.

And here's an example of what one specific group of respondents saw (the group that was assigned the condition in which a gay couple is refused services by a self-employed photographer for religious reasons):

Michael and Jason, a gay couple, are getting married and want to have photos taken to send out with their wedding invitations. They went to a self-employed photographer because they heard he was the best photographer in the area for engagement portraits. The photographer refused to take their picture. He explained that because he is religious he doesn't approve of gay marriage.

After they read the vignette, we asked respondents to say whether they thought the business should be able to refuse services or should have to provide the same services they provide to other customers. As expected, we found that Americans were more likely to support refusal by a self-employed individual than by a corporation. But the results for the other two factors surprised us. As shown in Figure 2 (which combines both the self-employed and corporation conditions), Americans were just as likely to support refusal to same-sex couples for explicitly non-religious reasons as for religious reasons. And many Americans were okay with refusing services on the basis of race. Given that the debates about service-refusal were focused on questions of religious liberty, we had expected that Americans would be more likely to support refusal for religious reasons than non-religious reasons. But rather than respondents privileging religion as a basis for refusal, they supported refusal or didn't support refusal regardless of whether it was for religious reasons or not. In further analyses we found that this support was largely a function of respondents' own support for or opposition to marriage rights. In other words, if people opposed 
same-sex marriage themselves, they were more likely to support refusal regardless of whether or not it was for religious reasons or not.

Figure 2: Support for Business Service Refusal by Type of Couple Refused and Reason for Refusal

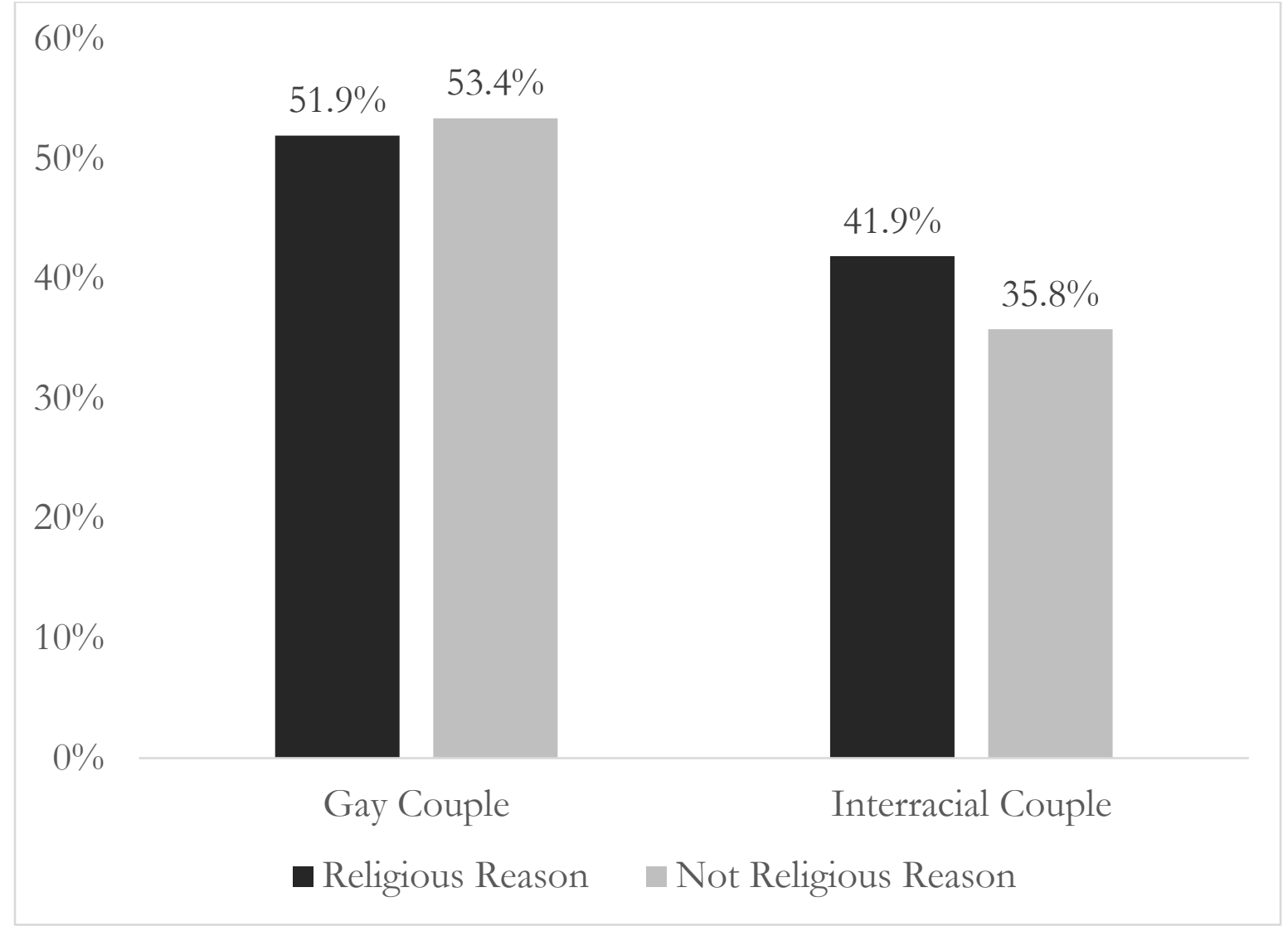

We also asked respondents to explain why they did or did not support the business' choice to refuse services. We found that people largely gave similar explanations for why they opposed or why they supported refusal regardless of whether the refusal was for religious or non-religious reasons. The people who said the business should have to provide the same services it would to other customers were largely consistent in their reasoning regardless of which scenario they read about. To them, denial of service to any minority group is discrimination, regardless of the reason for refusal. In fact, several people who read about a same-sex couple refused services- 
and who would not have seen the parallel interracial couple vignettes-equated denial of services to gay couples with historical denial of services to African Americans. In contrast, the plurality of respondents who supported the businesses' right to refuse services framed their support in terms of individual rights and libertarianism, regardless of whether they read about a religious or a non-religious reason for refusal. Others who endorsed refusal expressly said they supported the businesses' right to refuse because of their own opposition to same-sex relationships, again regardless of the reason for refusal. If you'd like to read more about the study, you can find an open-access copy of it on the journal's website at http://advances.sciencemag.org/content/3/12/eaao5834 (Powell, Schnabel, Apgar 2017; also see Powell, Schnabel, Apgar 2018).

Before moving on to other examples, I'd like to highlight an important practical point: the more complex your design, the more complicated everything will be. When varying more aspects of a vignette, for example, every additional factor you vary leads to multiplicative rather than just additive complexity. Our experiment had just two versions of three different things, which led to eight different conditions. Had we varied one more thing we would have had 16 conditions, and 16 versions of the survey instrument, instead of eight. In pretests we did have an extra manipulation (whether or not there were other options for photography in the area), found that it didn't seem to affect the results, and decided to drop it to keep things simpler. Although some survey experiments have more conditions, fewer is often better. This point is especially important to remember when considering how large of a sample you'll need to have a sufficient statistical power for making comparisons across conditions.

Survey experiments have become increasingly common in the social scientific study of religion/s in recent years. Across the social sciences, researchers are using survey experiments to 
study everything from stereotypes about religious minorities to whether thinking about Richard Dawkins makes people see science and religion as more or less compatible. I'll summarize the key findings from a few relevant studies, and also provide a table that lists several types of survey experiments in the study of religion. In this summary-which is meant to be illustrative and not exhaustive of all the survey experiments on issues related to religion-I'll provide some information that highlights the range of approaches, samples, and disciplines using these methods (as you'll see, it's particularly common in political science).

Sociologists Christopher Scheitle and Elaine Howard Ecklund (2017) conducted a U.S. nationally-representative survey experiment in which they told respondents about science popularizers, having people read about either Francis Collins (who sees science and religion as more compatible) or Richard Dawkins (who sees science and religion as more incompatible). They found that reading about Dawkins and his views about religion not being compatible with science didn't have a significant impact on whether people themselves see science and religion as compatible or not. Although reading about Dawkins and his views didn't seem to matter, reading about Collins and his views on religion and science being compatible increased the likelihood that respondents saw religion and science as compatible. The authors suggested that because many people assume scientists are antagonistic to religion, reading about a scientist (Dawkins) who is opposed to religion isn't too surprising. But it is more surprising, and thus impactful, to read about a scientist (Collins) who sees religion and science as fully compatible.

Political scientist Michele Margolis (2018) conducted a two-wave survey experiment with a U.S. diverse national sample on whether and how politics affects religion. In the first wave of the survey respondents were asked about their partisanship. Two weeks later there was a follow-up survey of the same respondents and the experimental component was administered. 
The respondents were shown event flyers and asked which ones were better. One group was asked to evaluate flyers about political events matched to their stated party affiliation to prime partisan identity (i.e., make people think about politics), while the other group didn't view any flyers. Respondents then answered questions about their religious identification and the strength of their religious identity. Republicans who viewed flyers about Republican events identified as more strongly religious than Democrats who viewed flyers about Democratic events (with the impact primarily operating among people with children in the home). In other words, priming partisan identities (i.e., making people think about their political views) can impact how religious people say they are.

Political scientists Tarek Masoud, Amaney Jamal, and Elizabeth Nugent (2016) used a survey experiment to explore the impact of exposing people to an argument in favor of women's political equality grounded in the Qur'an. Their study participants were nationally-representative of Egypt. The researchers found that people who were exposed to an argument for women's equality grounded in Islamic scriptures were significantly more willing to approve of women's political leadership than those exposed to a non-religious argument in favor of women's leadership. The authors concluded that whereas religion is often used to justify the political exclusion of women, it can be reinterpreted and leveraged to empower rather than exclude women as leaders.

Political scientist Taylor Boas conducted a survey experiment to explore the impact of a candidate's professional titles such as "pastor" (e.g., "Pastor Paulo") and "doctor" (e.g., "Doctor Carlos") on voting for municipal elections in Brazil. The sample for the study was an opt-in internet sample, with respondents recruited via ads posted on Facebook. The ads were set to target adult Brazilian Facebook users with the offer of a chance of winning an iPad in exchange 
for completing the survey. The study found that professional titles for candidates in lowinformation local elections (i.e., elections in which voters don't know much about the candidates) impacted how likely respondents were to say they would vote for them. Having "pastor" as a title decreased the likelihood that people would vote for a candidate. The study showed that the decrease in voting intention for candidates with the title "pastor" is driven by non-evangelicals; among evangelicals, the title "pastor" increased vote intention.

Psychologist Nicholas Epley and several colleagues (2009) conducted a survey experiment on how people estimate what God's perspective is on social issues, and whether and how reading opposing arguments on affirmative action could change what people say that God thinks. Respondents were assigned to either a condition in which they read a strong argument for affirmative action and a weak argument against it, or a strong argument against it and a weak argument for it. The researchers found that not only did people who read a strong argument for affirmative action support affirmative action more themselves, but they were also more likely to think that God is in favor of affirmative action. In other words, the researchers found that people's own views can be affected by a persuasive argument, and if they support something themselves they're more likely to think that God supports it too (i.e., they believe that God thinks whatever they think).

These are just a few survey experiments that have been conducted on issues related to religion. The following table provides information about several other survey experiments. This list is meant to be illustrative, not exhaustive. As you'll see in Table 1, there's a preponderance of vignette-based survey experiments conducted by political scientists. And although there's some diversity in the countries considered (especially in the last five years or so), there's plenty of room for survey experiments in more countries with a broader range of religious cultures. 
Table 1: Survey Experiments on Religion

\begin{tabular}{|c|c|c|c|c|c|c|}
\hline Year & Title & Discipline $^{\mathrm{a}}$ & $\begin{array}{c}\text { Treatment } \\
\text { Type }\end{array}$ & $\begin{array}{l}\text { Delivery } \\
\text { Method }\end{array}$ & Sample & Country \\
\hline 1987 & $\begin{array}{l}\text { An experimental study of the } \\
\text { influence of religious elites on public } \\
\text { opinion }\end{array}$ & $\begin{array}{l}\text { Political } \\
\text { Science }\end{array}$ & $\begin{array}{l}\text { Vignette/ } \\
\text { Source } \\
\text { Attribution } \\
\end{array}$ & In person & $\begin{array}{l}\text { Undergraduates } \\
\text { at two religious } \\
\text { colleges } \\
\end{array}$ & U.S. \\
\hline 2005 & $\begin{array}{l}\text { The indirect effects of discredited } \\
\text { stereotypes }\end{array}$ & $\begin{array}{l}\text { Political } \\
\text { Science }\end{array}$ & Vignette & Phone & $\begin{array}{l}\text { Nationally- } \\
\text { representative }\end{array}$ & U.S. \\
\hline 2009 & $\begin{array}{l}\text { God talk: Religious cues and electoral } \\
\text { support }\end{array}$ & $\begin{array}{l}\text { Political } \\
\text { Science }\end{array}$ & $\begin{array}{l}\text { Pictures and } \\
\text { Bios }\end{array}$ & In person & $\begin{array}{l}\text { Undergraduates } \\
\text { at Texas A\&M }\end{array}$ & U.S. \\
\hline 2009 & $\begin{array}{l}\text { Believers' estimates of God's beliefs } \\
\text { are more egocentric than estimates of } \\
\text { other people's beliefs }\end{array}$ & Psychology & Vignette & Online & $\begin{array}{l}\text { Not clear, likely } \\
\text { a diverse } \\
\text { national sample }\end{array}$ & U.S. \\
\hline 2010 & $\begin{array}{l}\text { Evangelizing the environment: } \\
\text { Decision process effects in political } \\
\text { persuasion }\end{array}$ & $\begin{array}{l}\text { Political } \\
\text { Science }\end{array}$ & Vignette & Online & $\begin{array}{l}\text { Nationally- } \\
\text { representative }\end{array}$ & U.S. \\
\hline 2012 & $\begin{array}{l}\text { Anti-atheist bias in the United States: } \\
\text { Testing two critical assumptions }\end{array}$ & Psychology & Vignette & Online & $\begin{array}{l}\text { Nationally- } \\
\text { representative }\end{array}$ & U.S. \\
\hline 2012 & $\begin{array}{l}\text { Courting Christians: How political } \\
\text { candidates prime religious } \\
\text { considerations in campaign ads }\end{array}$ & $\begin{array}{l}\text { Political } \\
\text { Science }\end{array}$ & $\begin{array}{l}\text { Campaign } \\
\text { Websites and } \\
\text { Videos } \\
\end{array}$ & Online & $\begin{array}{l}\text { Nationally- } \\
\text { representative }\end{array}$ & U.S. \\
\hline 2013 & $\begin{array}{l}\text { Divine intervention? The influence of } \\
\text { religious value communication on U.S. } \\
\text { intervention policy }\end{array}$ & $\begin{array}{l}\text { Political } \\
\text { Science }\end{array}$ & $\begin{array}{l}\text { Values } \\
\text { Priming }\end{array}$ & In person & $\begin{array}{l}\text { Attendees at } 9 \\
\text { houses of } \\
\text { worship }\end{array}$ & U.S. \\
\hline 2013 & $\begin{array}{l}\text { Religious value priming, threat, and } \\
\text { political tolerance }\end{array}$ & $\begin{array}{l}\text { Political } \\
\text { Science }\end{array}$ & $\begin{array}{l}\text { Values } \\
\text { Priming }\end{array}$ & Phone & $\begin{array}{l}\text { Representative } \\
\text { of Greene } \\
\text { County, MO }\end{array}$ & U.S. \\
\hline 2013 & $\begin{array}{l}\text { Divine direction: How providential } \\
\text { religious beliefs shape foreign policy } \\
\text { attitudes }\end{array}$ & $\begin{array}{l}\text { Political } \\
\text { Science }\end{array}$ & Vignette & Online & $\begin{array}{l}\text { Nationally- } \\
\text { representative }\end{array}$ & U.S. \\
\hline 2014 & $\begin{array}{l}\text { Rights talk: The opinion dynamics of } \\
\text { rights framing }\end{array}$ & $\begin{array}{l}\text { Political } \\
\text { Science }\end{array}$ & $\begin{array}{l}\text { Candidate } \\
\text { Stances }\end{array}$ & In person & $\begin{array}{l}\text { Undergraduates } \\
\text { at four colleges }\end{array}$ & U.S. \\
\hline 2014 & $\begin{array}{l}\text { Pastor Paulo vs. Doctor Carlos: } \\
\text { Professional titles as voting heuristics } \\
\text { in Brazil }\end{array}$ & $\begin{array}{l}\text { Political } \\
\text { Science }\end{array}$ & Vignette & Online & $\begin{array}{l}\text { Sample from } \\
\text { Facebook ads }\end{array}$ & Brazil \\
\hline 2015 & $\begin{array}{l}\text { Anti-Americanism, authoritarian } \\
\text { politics, and attitudes about women's } \\
\text { representation: Evidence from a } \\
\text { survey experiment in Jordan }\end{array}$ & $\begin{array}{l}\text { Political } \\
\text { Science }\end{array}$ & Vignette & In person & $\begin{array}{l}\text { Nationally- } \\
\text { representative }\end{array}$ & Jordan \\
\hline 2015 & $\begin{array}{l}\text { Does Islam play a role in anti- } \\
\text { immigrant sentiment? An } \\
\text { experimental approach }\end{array}$ & Sociology & $\begin{array}{l}\text { List } \\
\text { Experiment }\end{array}$ & Online & $\begin{array}{l}\text { Nationally- } \\
\text { representative }\end{array}$ & U.S. \\
\hline 2015 & $\begin{array}{l}\text { Is it gender, religiosity or both? A role } \\
\text { congruity theory of candidate } \\
\text { electability in transitional Tunisia }\end{array}$ & $\begin{array}{l}\text { Political } \\
\text { Science }\end{array}$ & $\begin{array}{l}\text { Candidate } \\
\text { Photographs }\end{array}$ & In person & $\begin{array}{l}\text { Nationally- } \\
\text { representative }\end{array}$ & Tunisia \\
\hline 2015 & Religion and the Latin American voter & $\begin{array}{l}\text { Political } \\
\text { Science }\end{array}$ & Vignette & Online & $\begin{array}{l}\text { Sample from } \\
\text { Facebook ads }\end{array}$ & Brazil \\
\hline 2015 & $\begin{array}{l}\text { Dog-whistle politics: Multivocal } \\
\text { communication and religious appeals }\end{array}$ & $\begin{array}{l}\text { Political } \\
\text { Science }\end{array}$ & $\begin{array}{l}\text { Campaign } \\
\text { Videos }\end{array}$ & Online & $\begin{array}{l}\text { Diverse national } \\
\text { sample }\end{array}$ & U.S. \\
\hline 2016 & $\begin{array}{l}\text { Pastors for Pinochet: Authoritarian } \\
\text { stereotypes and voting for evangelicals } \\
\text { in Chile }\end{array}$ & $\begin{array}{l}\text { Political } \\
\text { Science }\end{array}$ & Vignette & Online & $\begin{array}{l}\text { Sample from } \\
\text { Facebook ads }\end{array}$ & Chile \\
\hline
\end{tabular}




\begin{tabular}{|c|c|c|c|c|c|c|}
\hline 2016 & $\begin{array}{l}\text { Using the Qur'ān to empower Arab } \\
\text { women? Theory and experimental } \\
\text { evidence from Egypt }\end{array}$ & $\begin{array}{l}\text { Political } \\
\text { Science }\end{array}$ & $\begin{array}{l}\text { Vignette/ } \\
\text { Religious Text } \\
\text { Prime }\end{array}$ & In person & $\begin{array}{l}\text { Nationally- } \\
\text { representative }\end{array}$ & Egypt \\
\hline 2017 & $\begin{array}{l}\text { Freedom of religion and freedom of } \\
\text { speech: The effects of alternative } \\
\text { rights frames on mass support for } \\
\text { public exemptions }\end{array}$ & $\begin{array}{l}\text { Political } \\
\text { Science }\end{array}$ & Vignette & Online & $\begin{array}{l}\text { Diverse national } \\
\text { sample }\end{array}$ & U.S. \\
\hline 2017 & $\begin{array}{l}\text { Denial of service to same-sex and } \\
\text { interracial couples: Evidence from a } \\
\text { national survey experiment }\end{array}$ & Sociology & Vignette & Online & $\begin{array}{l}\text { Nationally- } \\
\text { representative }\end{array}$ & U.S. \\
\hline 2017 & $\begin{array}{l}\text { The influence of science popularizers } \\
\text { on the public's view of religion and } \\
\text { science: An experimental assessment }\end{array}$ & Sociology & $\begin{array}{l}\text { Vignette/ } \\
\text { Prime }\end{array}$ & Online & $\begin{array}{l}\text { Nationally- } \\
\text { representative }\end{array}$ & U.S. \\
\hline 2017 & $\begin{array}{l}\text { Church or state? Reassessing how } \\
\text { religion shapes impressions of } \\
\text { candidate positions }\end{array}$ & $\begin{array}{l}\text { Political } \\
\text { Science }\end{array}$ & Vignette & Online & $\begin{array}{l}\text { Nationally- } \\
\text { representative }\end{array}$ & U.S. \\
\hline 2018 & $\begin{array}{l}\text { Arab responses to Western hegemony: } \\
\text { Experimental evidence from Egypt }\end{array}$ & $\begin{array}{l}\text { Political } \\
\text { Science }\end{array}$ & Priming & In person & $\begin{array}{l}\text { Nationally- } \\
\text { representative }\end{array}$ & Egypt \\
\hline 2018 & $\begin{array}{l}\text { How far does social group influence } \\
\text { reach? Identities, elites, and } \\
\text { immigration attitudes }\end{array}$ & $\begin{array}{l}\text { Political } \\
\text { Science }\end{array}$ & $\begin{array}{l}\text { Radio } \\
\text { advertisement }\end{array}$ & Online & $\begin{array}{l}\text { Diverse national } \\
\text { sample }\end{array}$ & U.S. \\
\hline 2018 & $\begin{array}{l}\text { How politics affects religion: } \\
\text { Partisanship, socialization, and } \\
\text { religiosity in America }\end{array}$ & $\begin{array}{l}\text { Political } \\
\text { Science }\end{array}$ & Event flyers & Online & $\begin{array}{l}\text { Diverse national } \\
\text { sample }\end{array}$ & U.S. \\
\hline $\begin{array}{l}\text { Forth- } \\
\text { coming }\end{array}$ & $\begin{array}{l}\text { Engendering empathy, begetting } \\
\text { backlash: American attitudes toward } \\
\text { Syrian refugees }\end{array}$ & $\begin{array}{l}\text { Political } \\
\text { Science }\end{array}$ & Priming & Online & $\begin{array}{l}\text { Diverse national } \\
\text { sample }\end{array}$ & U.S. \\
\hline $\begin{array}{l}\text { Working } \\
\text { Paper }\end{array}$ & $\begin{array}{l}\text { Culture and the persistence of } \\
\text { educational inequality: Lessons from } \\
\text { the Muslim-Christian education gap in } \\
\text { Africa }\end{array}$ & $\begin{array}{l}\text { Political } \\
\text { Science }\end{array}$ & Photographs & In person & $\begin{array}{l}\text { Representative } \\
\text { of two districts }\end{array}$ & Malawi \\
\hline $\begin{array}{l}\text { Working } \\
\text { Paper }\end{array}$ & $\begin{array}{l}\text { Preferences for descriptive } \\
\text { representation: Asymmetries between } \\
\text { Hindus and Muslims in India }\end{array}$ & $\begin{array}{l}\text { Political } \\
\text { Science }\end{array}$ & Photographs & In person & Multiple samples & India \\
\hline
\end{tabular}

${ }^{\text {a }}$ Discipline determined by first author's discipline

\section{Conclusion}

When is a survey experiment a religion survey experiment? Any time at least one of the

following has something to do with religion: 1) the treatment, 2) the outcome, or 3) the sample.

These three things - the treatment, the outcome, and the sample - are key components of any

experiment. With survey experiments, the treatment is a vignette or some other survey-based

treatment (which in online surveys can include multimedia), the outcomes are closed or open-

ended survey question(s) (though other factors can be measured, such as speed of response as in 
implicit bias tests), and the sample is often more diverse than lab experiments (though a survey experiment could be conducted with lab participants or other convenience samples).

We're seeing a rapid increase in the number of survey experiments on religion, but we're only beginning to scratch the surface of the many ways survey experiments could be used to study religion. Like any method survey experiments have their limitations, and not all questions about religion and society can be best addressed with survey experiments. But when appropriate for something you're wondering the world, survey experiments can provide unique leverage on both causality and generalizability.

\section{References}

Adida, C., Lo, A. and Platas, M., Forthcoming. Engendering empathy among Americans can promote inclusionary behavior toward Syrian refugees. Proceedings of the National Academy of Sciences, in press.

Albertson, B., 2015. Dog-whistle politics: multivocal communication and religious appeals. Political Behavior, 37(1): 3-26.

Benstead, L.J., Jamal, A.A. and Lust, E., 2015. Is it gender, religiosity or both? a role congruity theory of candidate electability in transitional Tunisia. Perspectives on Politics 13(1): 7494.

Berinsky, A. and Mendelberg, T., 2005. The indirect effects of discredited stereotypes. American Journal of Political Science 49(4): 845-64.

Boas, T., 2014. Pastor Paulo vs. Doctor Carlos: professional titles as voting heuristics in Brazil. Journal of Politics in Latin America 2: 39-72.

Boas, T.C., 2016. Pastors for Pinochet: authoritarian stereotypes and voting for Evangelicals in Chile. Journal of Experimental Political Science 3(2): 197-205.

Boas, T. and Smith, A.E., 2015. Religion and the Latin American voter. In" R. Carlin, M. Singer, and E. Zechmeister (eds.), The Latin American Voter. Ann Arbor, MI: University of Michigan Press.

Bush, S.S. and Jamal, A.A., 2015. Anti-Americanism, authoritarian politics, and attitudes about women's representation: evidence from a survey experiment in Jordan. International Studies Quarterly 59(1): 34-45. 
Calfano, B.R. and Djupe, P.A., 2009. God talk: religious cues and electoral support. Political Research Quarterly 62(2): 329-39.

Chhibber, P., Working Paper. Preferences for descriptive representation: asymmetries between Hindus and Muslims in India.

Creighton, M.J. and Jamal, A., 2015. Does Islam play a role in anti-immigrant sentiment? An experimental approach. Social Science Research 53: 89-103.

Difallah, D., Filatova, E. and Ipeirotis, P. 2018. "Demographics and dynamics of Mechanical Turk workers." In Proceedings Of WSDM 2018: The Eleventh ACM International Conference on Web Search and Data Mining 135-43.

Djupe, P.A. and Calfano, B.R., 2013. Divine intervention? the influence of religious value communication on U.S. intervention policy. Political Behavior 35(4): 643-63.

Djupe, P.A. and Calfano, B.R., 2013. Religious value priming, threat, and political tolerance. Political Research Quarterly 66(4): 768-80.

Djupe, P.A. and Gwiasda, G.W., 2010. Evangelizing the environment: Decision process effects in political persuasion. Journal for the Scientific Study of Religion 49(1): 73-86.

Djupe, P.A. et al., 2014. Rights talk: the opinion dynamics of rights framing. Social Science Quarterly 95(3): 652-68.

Epley, N. et al., 2009. Believers' estimates of God's beliefs are more egocentric than estimates of other people's beliefs. Proceedings of the National Academy of Sciences 106(51): 2153338.

Glazier, R.A., 2013. Divine direction: how providential religious beliefs shape foreign policy attitudes. Foreign Policy Analysis 9(2): 127-142.

Jelen, T.G., Lewis, A.R. and Djupe, P.A., 2017. Freedom of religion and freedom of speech: the effects of alternative rights frames on mass support for public exemptions. Journal of Church and State 60(1): 43-67.

Lewis, A.R. et al., 2015. The (non)religion of Mechanical Turk workers. Journal for the Scientific Study of Religion 54(2): 419-428.

Margolis, M.F., 2018. How far does social group influence reach? identities, elites, and immigration attitudes. Journal of Politics 80(3): 772-85.

Margolis, M.F., 2018. How politics affects religion: partisanship, socialization, and religiosity in America. The Journal of Politics 80(1): 30-43. 
Masoud, T., Jamal, A. and Nugent, E., 2016. Using the Qur'ān to empower Arab women? Theory and experimental evidence from Egypt. Comparative Political Studies 49(12): $1555-98$.

Mckeown, B. and Carlson, J., 1987. An experimental study of the influence of religious elites on public opinion. Political Communication 4(2): 93-102.

Nugent, E., Masoud, T. and Jamal, A.A., 2018. Arab responses to Western hegemony: experimental evidence from Egypt. Journal of Conflict Resolution 62(2): 254-88.

Platas, M.R., Working Paper. Culture and the persistence of educational inequality: lessons from the Muslim-Christian education gap in Africa.

Powell, B., Schnabel, L. and Apgar, L., 2017. Denial of service to same-sex and interracial couples: Evidence from a national survey experiment. Science Advances 3(12): 1-7.

Powell, B., Schnabel, L. and Apgar, L., 2018. Freedom to discriminate. Contexts 17(2): 73-75.

Scheitle, C. and Ecklund, E.H., 2017. The influence of science popularizers on the public's view of religion and science: An experimental assessment. Public Understanding of Science 26(1): 25-39.

Simas, E.N. and Ozer, A.L., 2017. Church or state? Reassessing how religion shapes impressions of candidate positions. Research and Politics, April-June: 1-5.

Swan, L. and Heesacker, M., 2012. Anti-atheist bias in the United States: testing two critical assumptions. Secularism and Nonreligion, 42: 32-42.

Weber, C. and Thornton, M., 2012. Courting Christians: how political candidates prime religious considerations in campaign ads. Journal of Politics 74(2): 400-413.

\section{Further readings}

Auspurg, K. and Hinz, T., 2015. Factorial Survey Experiments. SAGE Publications, Thousand Oaks, CA.

An overview of factorial survey experiments. This short book is part of the SAGE "Little Green Books" series, which seeks to provide brief and affordable introductions to various research methods.

Mutz, D., 2011. Population-Based Survey Experiments, Princeton, NJ: Princeton University Press. 
An overview of population-based survey experiments by Diana Mutz, one of the founders of the Time-Sharing for the Social Sciences (TESS) program.

Freese, J. and Druckman, J., 2019. Introducing TESS. Time-Sharing Experiments for the Social Sciences (TESS). Available at: http://www.tessexperiments.org/introduction.html.

Information about TESS - including some basic information about population-based survey experiments-and how you can submit a proposal for your own population-based survey experiment.

For examples of studies applying these methods to the study of religion, see the summary table in the chapter (and the accompanying citations in the references section).

\section{Key concepts}

Causality: The relationship between a cause and its effect. That which connects one factor with another in such a way that the one factor leads to the second, and the second is, at least in part, dependent on the first. When social scientists talk about causality, their focus is often on the mechanisms explaining whether and why there is, or is not, a causal relationship between two factors or processes. Or, to put it another way, whether a relationship is real (i.e., one thing makes the other happen) or spurious (i.e., the two things are correlated, but not because one causes the other).

Control group: In an experiment, the control group is the one against which the treatment group (i.e., the group to which something was done) is compared. In medical experiments this is the group that receives the placebo or "sugar pill" instead of the treatment.

Correlation: An association between two factors that may or may not be causal (i.e., they are related to one another, but there can be correlation without either of the factors influencing the other one).

Directionality: This refers to the direction of a relationship, especially as it pertains to which factor causes the other. Sometimes this is obvious (taking a pill can cure a disease, the cure of a disease cannot cause someone to take a pill), and other times it's harder to determine (attending religious services could make you healthier, or being healthier could make you more likely to attend religious services).

Diverse national sample: A sample is a diverse national sample when it includes people from around the nation of different groups and backgrounds but is not population-based. It could be matched to some population parameters to make it approximate a representative sample, but it uses non-random subject selection.

Generalizability (also external validity): A study has external validity and is thus generalizable when researchers can draw implications about a broader population than those in the study. A 
study is more generalizable when it has a careful sampling frame based on the population of interest, which allows researchers to make claims with a level of confidence about the population as a whole.

Nationally-representative: A survey is nationally-representative when it is population-based and the population of interest is the people in a nation. In other words, it is a random sample of the nation in which, at least in theory, every person had an equal chance of being selected for the study. It allows you to generalize the findings from the sample to the population of people in the nation.

Panel: A group of respondents recruited to regularly complete surveys. A survey panel can be representative of a target population (e.g., all people in a country) if respondents are recruited using population-based methods. You can maintain your own survey panel, or pay to have your survey conducted on a sample from a research organization's panel.

\section{Population: please use definition from revised survey chapter}

Population-based survey: A survey experiment with a strategic sampling frame based on the population of interest. In other words, those filling out the survey represent the population of interest, and the results from the survey experiment can generalize to that population.

Prime: A prime is something frequently used in laboratory experiments where people are exposed to something earlier that may influence how they respond to later questions - often without being consciously aware that their response was shaped by what they were shown earlier. A prime could involve presenting some subjects with just a single word, something more complex like having them read or watch something, or, when it's done in a lab environment, you could even expose people to an experience or have them participate in an activity.

Sample: please use definition from revised survey chapter

Subject (also participant): please use definition from revised experiments chapter

Survey: please use definition from revised survey chapter

Survey experiment: A survey experiment is simply an experiment conducted on a survey.

Treatment: A treatment is that to which a researcher exposes study participants. The treatment group (which is exposed to something) is the inverse of the control group (which is not exposed to that thing). In medical research it might be a medical treatment, and in the empirical study of religion it might be a vignette, a prime, or some other experimental manipulation to which people are exposed at random.

Vignettes: Short stories or descriptions of scenarios in which elements of the situation are varied and after which you ask people to evaluate someone or something about the scenario. 
Biographical note: Landon Schnabel is a doctoral candidate in sociology at Indiana University. His current research focuses on social inequality, gender, sexualities, religion, and politics. He is writing a book about how religions are gender-typed. 